\title{
THE THERMAL POWER PLANTS WITH THE VIEWPOINT OF FARMERS: THE CASE OF AMASYA PROVINCE
}

\author{
ERDAL, H. ${ }^{1}-$ ERDAL, G. ${ }^{2}-$ AYYILDIZ, B. ${ }^{3}-$ AYYILDIZ, M. ${ }^{3}$ \\ ${ }^{1}$ Department of Management and Organization, Social Sciences Vocational School, Tokat \\ Gaziosmanpasa University, Tokat, Turkey \\ ${ }^{2}$ Department of Agricultural Economics, Faculty of Agriculture, Tokat Gaziosmanpasa \\ University, Tokat, Turkey \\ ${ }^{3}$ Department of Agricultural Economics, Faculty of Agriculture, Yozgat Bozok University, \\ Yozgat, Turkey \\ *Corresponding author \\ e-mail:glerdal2@yahoo.com
}

(Received $13^{\text {th }}$ May 2019; accepted $30^{\text {th }}$ Jan 2020)

\begin{abstract}
Thermal power plants are facilities that convert the chemical energy of solid, liquid and gas fuels respectively into thermal, mechanical and electric energy. The presumption of establishing a fossil fuel plant on this fertile area is putting the security of the agricultural products of the area at risk. A face to face survey was carried out with the 90 of the farmers living close to the planned area for the establishment of the fossil fuel plant in Suluova county of Amasya province. According to the survey results $43 \%$ of the farmers stated that fossil fuel plant is a necessity but it should be established far away from the agricultural estates whereas $30 \%$ of them think that these kind of fuel plants should not be established on any account and $27 \%$ of them expressed no opinion about the issue. A total of $60 \%$ of the farmers think that the agricultural consequences of the planned fossil fuel plant are not considered adequately; and $73 \%$ of the farmers think that a presumed fossil fuel plant in the area will negatively affect the yield and the quality of the agricultural products and 56\% say that the agricultural estates will be negatively affected by it. Majority of the farmers stated that they would try to prevent the establishment of the plant even if they knew they would not succeed.
\end{abstract}

Keywords: farmer, agriculture, thermal power plant, Amasya, pollution

\section{Introduction}

Thermal power plants are the plants that convert the thermal energy of solid, liquid and gaseous fossil fuels into electrical energy. In this context, there are coal power plants, fuel-oil power plants and natural gas power plants. On the other hand, the plants that produce electricity from biomass are considered as thermal power plants (Chamber of Mechanical Engineers, 2017). It is stated that thermal power plants are preferred to produce electricity because of their advantages like being established with low costs and rapid feasibility and making use of the low-quality coal (Karaca et al., 2005).

As of late 2016, electricity production was $273,387 \mathrm{GWh}$, and $184,889 \mathrm{GWh}$ of it was produced by thermal power plants in Turkey, 67,268 GWh was produced from hydroelectric plants, and 21,230 GWh from other renewable energy sources. In the same period, the rate of the electricity that was produced by thermal power plants to total electricity generation was $67.6 \%$. Coal-originated power plants ranked the first in this rate with a share of $33.74 \%$, followed by natural gas + LNG-based power plants with a rate of $32.1 \%$, and followed by hydraulic power plants with $24.6 \%$. As of the end 
of 2016, it was of great importance that the share of electricity produced in wind power plants increased in total production from $3.4 \%$ to $5.7 \%$ (Table 1).

Table 1. Distribution of electricity production of Turkey according to energy sources $(G W h)$ (Ministry of Energy and Natural Sources, 2018)

\begin{tabular}{|c|c|c|c|c|c|c|c|}
\hline \multirow{2}{*}{\multicolumn{2}{|c|}{ Primary energy source }} & \multicolumn{2}{|c|}{2014} & \multicolumn{2}{|c|}{2015} & \multicolumn{2}{|c|}{2016} \\
\hline & & \multirow{2}{*}{$\begin{array}{c}\begin{array}{c}\text { Production } \\
\text { (GWh) }\end{array} \\
39,647\end{array}$} & \multirow{2}{*}{$\begin{array}{c}\begin{array}{c}\text { Share } \\
(\%)\end{array} \\
15.7\end{array}$} & \multirow{2}{*}{$\begin{array}{c}\begin{array}{c}\text { Production } \\
\text { (GWh) }\end{array} \\
44,830\end{array}$} & \multirow{2}{*}{$\begin{array}{c}\text { Share } \\
(\%)\end{array}$} & \multirow{2}{*}{$\begin{array}{c}\begin{array}{c}\text { Production } \\
\text { (GWh) }\end{array} \\
53,778\end{array}$} & \multirow{2}{*}{$\begin{array}{c}\begin{array}{c}\text { Share } \\
(\%)\end{array} \\
19.67\end{array}$} \\
\hline Coal & $\begin{array}{c}\text { Mineral coal } \\
+ \text { imported coal } \\
+ \text { asphaltite } \\
\end{array}$ & & & & & & \\
\hline & Lignite & 36,615 & 14.5 & 31,336 & 11.97 & 38,460 & 14.07 \\
\hline \multirow{4}{*}{$\begin{array}{l}\text { Liquid } \\
\text { fuels }\end{array}$} & Fuel oil & 1,663 & 0.66 & 980 & 0.37 & 1,103 & 0.40 \\
\hline & Diesel oil & 482 & 0.19 & 1,244 & 0.48 & 1,548 & 0.57 \\
\hline & LPG & & 0.00 & & 0.00 & & 0.00 \\
\hline & Naphtha & & 0.00 & & 0.00 & 2 & 0.00 \\
\hline \multicolumn{2}{|c|}{ Natural gas + Lng } & 120,576 & 47.9 & 99,219 & 37.9 & 87,820 & 32.1 \\
\hline \multicolumn{2}{|c|}{ Renewable + wastes } & 1,433 & 0.57 & 1,758 & 0.67 & 2,179 & 0.80 \\
\hline \multicolumn{2}{|c|}{ Thermal } & 200,417 & 79.5 & 179,366 & 68.52 & 184,889 & 67.63 \\
\hline \multicolumn{2}{|c|}{ Hydraulic } & 40,645 & 16.1 & 67,146 & 25.6 & 67,268 & 24.6 \\
\hline \multicolumn{2}{|c|}{ Wind } & 8,520 & 3.4 & 11,652 & 4.45 & 15,492 & 5.67 \\
\hline \multicolumn{2}{|c|}{ Geothermal } & 2,364 & 0.9 & 3,424 & 1.31 & 4,767 & 1.74 \\
\hline \multicolumn{2}{|c|}{ Solar } & 17 & 0.01 & 194 & 0.07 & 972 & 0.36 \\
\hline \multicolumn{2}{|c|}{ General sum } & 251,963 & 100.00 & 261,783 & 100.00 & 273,387 & 100.00 \\
\hline
\end{tabular}

According to the data provided by Energy Market Regulatory Authority (EMRA), the domestic coal-fired power plants that are in operation in Turkey with production license are 34 in number; and one of them works on asphaltite, one on hard coal and the other is a lignite-fired power plant. There are also 6 power plants that are still under construction. The total installed capacity of the domestic coal, lignite and asphaltitefired power plants was 9,842 MW at the end of 2016. A total of 38,460,314,490 kWh electricity was produced in lignite-fired power plants in 2016 in terms of capacity in production (Table 2).

The number of the plants in operation that have production license in Turkey with imported Coal is 10 . There are also 7 other plants that are still under construction. The total established power of thermal power plants that run on imported coal is 7,571.4 MWe. A total of 53,777,704,022 $\mathrm{kWh}$ electricity was produced in 2016 in imported coal and hard coal-fired power plants. Although the number of natural gasfired power plants that have production license is 326 in Turkey, those that are active are 252 in number. A total of 104 of these have over $10 \mathrm{MW}$ capacity. The total established capacity of natural gas-fired thermal power plants was 22,156 MW as of the end of 2016. The total production of natural gas-fired power plants was $87,797,441,063 \mathrm{kWh}$ in 2016 (EMRA, 2018).

The very fine ash particles, which are drawn upwards by the gases in chimneys because of the combustion in thermal power plants are considered to be important waste materials. It was reported that millions of ash, cinder and particles produced as waste by coal that is burnt in the power plants are stored at a certain height over a land of thousands of hectares and cause intense ash emission on forests, marquis, agricultural areas and residential areas (Pacyna, 1987). 
Table 2. Coal-fired thermal power plants that have production licenses and $400 \mathrm{MWe}$ and above capacity in Turkey (EPDK, 2018)

\begin{tabular}{c|c|c|c|c}
\hline Fuel type & Name of the plant & City-county of plant & $\begin{array}{c}\text { Established } \\
\text { power } \\
\text { (MWe) }\end{array}$ & $\begin{array}{c}\text { Capacity in } \\
\text { production } \\
\text { (MWe) }\end{array}$ \\
\hline Imported coal & Çatalağzı Thermal Power Plant & Zonguldak-Merkez & $2,790.00$ & $2,790.00$ \\
Domestic coal & Afşin - Elbistan B & Kahramanmaraş-Af̧̧in & $1,440.00$ & $1,440.00$ \\
Domestic coal & Afşin - Elbistan A & Kahramanmaraş-Af̧̧in & $1,355.00$ & $1,355.00$ \\
Imported coal & İskenderun Thermal Power Plant & Adana-Yumurtalık & $1,210.00$ & $1,210.00$ \\
Imported coal & İÇTAŞ Elektrik Enerjisi Üretim & Çanakkale-Biga & $1,200.00$ & $1,200.00$ \\
Imported coal & Atlas Thermalım Inc. & Hatay- İskenderun & $1,200.00$ & $1,200.00$ \\
Domestic coal & Soma B Thermal Power Plant & Manisa -Soma & 990.00 & 990.00 \\
Coal & Kemerköy Thermal Power Plant & Muğla- Milas & 630.00 & 630.00 \\
Coal & Yatağan Thermal Power Plant & Muğla- Yatağan & 630.00 & 630.00 \\
Domestic coal & Çayırhan Thermal Power Plant & Ankara-Nallıhan & 620.00 & 620.00 \\
Domestic coal & Seyitömer Thermal Power Plant & Kütahya- Merkez & 600.00 & 600.00 \\
Domestic coal & Kangal Thermal Power Plant & Sivas- Kangal & 457.00 & 457.00 \\
Domestic coal & Tufanbeyli Thermal Power Plant & Adana -Tufanbeyli & 450.00 & 450.00 \\
Domestic coal & Yeniköy Thermal Power Plant & Muğla -Milas & 420.00 & 420.00 \\
Domestic asphaltite & Silopi Thermal Power Plant & Şırnak-Silopi & 405.00 & 405.00 \\
\hline
\end{tabular}

Numerous studies were carried out in the literature on thermal power plants. The importance of thermal power plants, environmental effects and their effects on the chemical properties of soil and microbial activity have been focused on in these studies (Adriano et al., 1980; Bunzl et al., 1983; Mejsrik and Suacha, 1988; Karaca, 1997; Onacak, 1999; Baba et al., 2003; Karaca et al., 2005; Deniz, 2010; Özcan et al., 2014).

In the present study, the awareness levels, judgments and attitudes of the farmers that continue agricultural activities in Suluova County in Amasya province where a thermal power is intended to be built were examined. Suluova County is a green plain that has fertile soils. The county is one of the locomotive regions of the city in terms of economic production with the factory that processes sugar beet, with four mine quarries, with onion and wheat cultivation, and with animal husbandry because the area is also suitable for agricultural production. Gürmin Enerji Madencilik Sanayi ve Tic. Inc. intends to build a thermal power plant within the boundaries of Merzifon and Suluova in the region with a total established capacity of $450 \mathrm{MW}$. The company made the application for the project in 2013, and EMRA approved the project. However, the objections on the power plant that would be established in the region where there was agricultural production, and the lack of the viewpoints of relevant institutions which failed to submit their investigation results at the $2^{\text {nd }}$ Examining and Evaluation Commission meeting caused that the Environmental Impact Assessment (EIA) process were ceased on August 25, 2016. During the 13 months as of this date, the Ministry of Environment and Urbanization decided to terminate the EIA process when there were no revised reports and when the company did not present any data. This result was not revealed at the questionnaire stage of our study (April, 2016). 


\section{Materials and methods}

The main material of the present study consisted of the data that were obtained with face-to-face interviews that were conducted with the farmers who lived in the villages of Suluova County of Amasya Province. In addition, the data that were provided by Energy Market Regulatory Authority and the Ministry of Energy and Natural Sources were also made use of. The study was conducted in 4 villages. In selecting the villages, the reactions to the thermal power plant that was intended to be established in the region were taken into consideration, and the farmers were selected with the Purposeful Sampling Method to represent the region. A total of 90 questionnaires were conducted with the farmers who lived in these 4 villages. The questionnaire was carried out in March and April 2016.

The findings that were obtained in the study are presented in the study in tables after calculating the percentages. The 5-Point Likert Scale was employed in designing the questions on the judgments of the farmers, and the average scores were calculated.

\section{Results and discussion}

Information on the enterprises and farmers who participated in the questionnaire are given in Table 3.

Table 3. Some information on the farmers and enterprises that were included in the study

\begin{tabular}{|c|c|}
\hline Average age & 46 \\
\hline Average income (\$) & $1,020.21$ \\
\hline Number of individuals of the enterprise family (persons) & 6 \\
\hline \multicolumn{2}{|l|}{ Educational status } \\
\hline Literate & 2.22 \\
\hline Primary School & 12.22 \\
\hline Secondary School & 31.11 \\
\hline High School & 48.89 \\
\hline College, faculty & 5.56 \\
\hline \multicolumn{2}{|l|}{ Income sources of the enterprise $(\%)$} \\
\hline Agriculture & 76.67 \\
\hline Free & 20.00 \\
\hline Paid public employee & 2.22 \\
\hline Pension & 1.11 \\
\hline \multicolumn{2}{|l|}{ Distribution of agricultural fields according to possession status (da) } \\
\hline Property field & 87.62 \\
\hline Partnership & 12.22 \\
\hline Rented & 84.99 \\
\hline \multicolumn{2}{|l|}{ Crops cultivated $(\%)$} \\
\hline Dry onion & 31.11 \\
\hline Sugar Beet & 26.67 \\
\hline Wheat & 16.67 \\
\hline Corn & 10.00 \\
\hline Potatoes & 10.00 \\
\hline Barley & 5.56 \\
\hline
\end{tabular}


The average age of the farmers who participated in the study was 46. It was observed that farmers were mostly secondary graduates $(31.11 \%)$, and high school graduates $(48.89 \%)$. The income level of the farmers was determined to be $1020,21 \$$. A total of $77 \%$ of the income sources of the enterprises that were included in the study came from agriculture, and $20 \%$ from free trade; and $88 \%$ of the farmers had property lands. In addition, they were also tenants at a rate of $85 \%$. When the products that were grown in the enterprises were examined, it was seen that dry onion was grown at the highest rate with a rate of $31.11 \%$, followed by sugar beet $(26.67 \%)$ and wheat $(16.67 \%)$.

The farmers were asked if they had heard the name "thermal power plant" before. It was determined that approximately $96 \%$ of the farmers knew thermal power plants (Table 4). Especially in recent years, they had intense discussions about thermal power plants. Despite this, $4 \%$ of the farmers stated that they did not hear the name "thermal power plant" before.

Table 4. Had the farmers heard of the name "thermal power plant" before?

\begin{tabular}{c|c}
\hline & Rate (\%) \\
\hline Yes & 95.56 \\
No & 4.44 \\
Total & 100.00 \\
\hline
\end{tabular}

The farmers who had heard the name "thermal power plant" and who were considered to have information on thermal power plants were asked about the establishment of the thermal power plants in their region. The results on this are given in Table 5. A total of $42.53 \%$ of the farmers had the same idea, which argued that thermal power plants must be established in our country; however, the place selection must be done very well. The rate of the farmers who thought that the energy that had to be produced with other means was $30 \%$. The rate of those who had no clear idea on this subject was $24 \%$.

Table 5. Opinions of the farmers on establishing thermal power plants in our country

\begin{tabular}{c|c}
\hline & Rate (\%) \\
\hline Establishing thermal power plants is compulsory, they must definitely be established & 3.45 \\
They must definitely be established, but place selection must be made more accurately & 42.53 \\
They must definitely not be established; other ways must be found to produce energy & 29.89 \\
I do not have a clear idea about this & 24.14 \\
Total & 100.00 \\
\hline
\end{tabular}

On the other hand, more than half of the farmers who participated in the questionnaire $(51.72 \%)$ claimed that it was completely wrong to establish Thermal Power Plant in the region that was close to their living area where they performed their agricultural activities. The rate of the farmers who thought that the establishment of the power plant in the region was the right decision remained as $1 \%$. The rate of the farmers who did not have any ideas on this subject was $24.14 \%$ (Table 6).

The farmers thought that the agricultural effects of the thermal power plant that would be established in the Suluova region were not considered fully, and the necessary 
sensitivity was not considered (Table 7). As a matter of fact, the EIA process was terminated due to objections and the lack of the opinions of the relevant institutions.

Table 6. Opinions of the farmers on the thermal power plant that was intended to be established in Suluova

\begin{tabular}{c|c}
\hline & Rate (\%) \\
\hline The establishment of the power plant in the region is suitable, this is a righteous decision & 1.15 \\
This could not have been established in this region, but this is not a very wrong decision & 22.99 \\
The power plant must definitely not be established in this region, this is a completely wrong decision & 51.72 \\
I have no idea & 24.14 \\
Total & 100.00 \\
\hline
\end{tabular}

Table 7. The opinions of the farmers on the sensitivity in place selection of the thermal power plant that was intended to be established in Suluova

\begin{tabular}{c|c}
\hline & Rate (\%) \\
\hline Yes, the place selection was very sensitive & 3.45 \\
No, the place selection was not very sensitive at all & 59.77 \\
I do not have any idea & 36.78 \\
Total & 100.00 \\
\hline
\end{tabular}

The opinions of the farmers on the negative impacts of the thermal power plant were examined and scored with a 5-point Likert scale. The farmers were asked to respond to the questions on the negative impacts as "very high-5"; "high-4"; "moderate-3"; "very low-2"; "none-1". The average scores were calculated by considering the answers of each farmer according to the score next to each answer. In this way, the common decisions of all the farmers who participated in the questionnaire were determined. The findings on this subject are given in Table 8.

Table 8. The opinions of the farmers on negative effects of the thermal power plant on their villages $(\%)$

\begin{tabular}{c|c|c|c|c|c|c}
\hline Negative effects on... & $\begin{array}{c}\text { Very high } \\
(\mathbf{5})\end{array}$ & $\begin{array}{c}\text { High } \\
\mathbf{( 4 )}\end{array}$ & $\begin{array}{c}\text { Moderate } \\
\mathbf{( 3 )}\end{array}$ & $\begin{array}{c}\text { Very low } \\
\text { (2) }\end{array}$ & $\begin{array}{c}\text { None } \\
\text { (1) }\end{array}$ & $\begin{array}{c}\text { Ave. } \\
\text { score }\end{array}$ \\
\hline the human health & 45.35 & 44.19 & 6.98 & 3.49 & 0.00 & 4.31 \\
the natural vegetation & 27.91 & 47.67 & 19.77 & 3.49 & 1.16 & 3.98 \\
the other creatures living in the region & 36.05 & 44.19 & 15.12 & 3.49 & 1.16 & 4.10 \\
the fertility of agricultural products & 36.05 & 48.84 & 11.63 & 3.49 & 0.00 & 4.17 \\
the quality of agricultural products & 38.37 & 47.67 & 11.63 & 2.33 & 0.00 & 4.22 \\
the image of the agricultural products & 11.63 & 53.49 & 19.77 & 9.30 & 5.81 & 3.56 \\
the air of the village & 13.95 & 43.02 & 19.77 & 10.47 & 12.79 & 3.35 \\
the environmental beauty of the village & 17.44 & 44.19 & 24.42 & 11.63 & 2.33 & 3.63 \\
the agricultural soils & 32.56 & 48.84 & 13.95 & 2.33 & 2.33 & 4.07 \\
\hline
\end{tabular}

As it may be seen in Table 8, the farmers thought that the thermal power plant will have negative impacts on human health, natural vegetation, the fertility of the agricultural 
products, the quality and appearance of the agricultural products, the air and environmental beauty of the village and on agricultural lands at a high rate. As a matter of fact, in many previous studies, it was stated that the environmental pollution elements that stemmed from the thermal power plant were air, soil and water pollution (Goncaoğlu et al., 2000). In one of the studies conducted on Afşin-Elbistan Thermal Power Plant, the effects of the ash caused by the power plant on the agricultural fields were examined, and it was determined that this caused the accumulation of heavy metals in the plants (Kahraman, 2011). It was determined that toxic dusts that contained $\mathrm{CO}_{2}, \mathrm{NO}$ and $\mathrm{SO}_{2}$ in the composition of the emissions coming from Afsin-Elbistan Thermal Power Plant chimneys caused burns in the leaves of the plants, and in this way, the leaves dried and eventually the trees dried (Özcan et al., 2014). Again, many researchers found that the emissions coming from thermal power plants had high heavy metal contents in the dominant wind directions, and that pollutant gases like Sulfur Dioxide $\left(\mathrm{SO}_{2}\right)$, Carbon Dioxide $\left(\mathrm{CO}_{2}\right)$ and Nitrogen Oxide (NOx) had negative impacts on some tree species (Aydemir, 2008; Karaca et al., 2007; Deniz, 2010).

In the present study, the judgments of the farmers were determined with more detailed questions depending on the features and negative effects of thermal power plants. The findings on this subject are given in Table 9.

Table 9. Judgments of the farmers on the characteristics of the thermal power plants (\%)

\begin{tabular}{|c|c|c|c|c|c|c|}
\hline Thermal power plants & $\begin{array}{l}\text { I definitely } \\
\text { agree } \\
\text { (5) }\end{array}$ & $\begin{array}{l}\text { I agree } \\
(4)\end{array}$ & $\begin{array}{l}\text { I do not have } \\
\text { any idea } \\
\text { (3) }\end{array}$ & $\begin{array}{l}\text { I do not } \\
\text { agree } \\
(2)\end{array}$ & \begin{tabular}{|c|} 
I definitely do \\
not agree \\
(1)
\end{tabular} & $\begin{array}{l}\text { Ave. } \\
\text { score }\end{array}$ \\
\hline $\begin{array}{c}\text {...may cause various diseases } \\
\text { depending on the fuel types used in } \\
\text { them }\end{array}$ & 55.81 & 40.70 & 0.00 & 2.33 & 1.16 & 4.48 \\
\hline ...may cause acid rains & 26.74 & 40.70 & 26.74 & 4.65 & 1.16 & 3.87 \\
\hline $\begin{array}{l}\text { The air pollution caused by thermal } \\
\text { power plants damage the living that } \\
\text { inhale this air }\end{array}$ & 47.67 & 46.51 & 2.33 & 2.33 & 1.16 & 4.37 \\
\hline ...damage forests & 27.91 & 59.30 & 8.14 & 3.49 & 1.16 & 4.09 \\
\hline $\begin{array}{c}\text {...the gasses produced slows down the } \\
\text { development of the vegetation }\end{array}$ & 29.07 & 51.16 & 16.28 & 3.49 & 0.00 & 4.06 \\
\hline ...damages the agricultural fields & 39.53 & 50.00 & 8.14 & 2.33 & 0.00 & 4.27 \\
\hline ...causes soil pollution & 47.67 & 41.86 & 8.14 & 2.33 & 0.00 & 4.35 \\
\hline ...causes desertification & 47.67 & 41.86 & 8.14 & 2.33 & 0.00 & 4.35 \\
\hline $\begin{array}{l}\text {...causes drops in the yield of } \\
\text { agricultural production }\end{array}$ & 53.49 & 36.05 & 6.98 & 3.49 & 0.00 & 4.40 \\
\hline $\begin{array}{c}\text {...causes disruptions in the quality of the } \\
\text { agricultural products }\end{array}$ & 47.67 & 40.70 & 8.14 & 3.49 & 0.00 & 4.33 \\
\hline $\begin{array}{l}\text {...the water used for cooling and } \\
\text { cleaning threatens the existence of the } \\
\text { water presence in the region }\end{array}$ & 36.05 & 53.49 & 8.14 & 1.16 & 1.16 & 4.22 \\
\hline ...pollutes the waters & 26.74 & 48.84 & 15.12 & 6.98 & 2.33 & 3.91 \\
\hline ...the damages are exaggerated & 3.49 & 8.14 & 33.72 & 32.56 & 22.09 & 2.38 \\
\hline $\begin{array}{l}\text {...the information on negative effects } \\
\text { are malevolent }\end{array}$ & 0.00 & 4.65 & 34.88 & 34.88 & 25.58 & 2.19 \\
\hline $\begin{array}{c}\text {...these plants are necessary and } \\
\text { beneficial for our country no matter } \\
\text { where they are established }\end{array}$ & 0.00 & 9.30 & 32.56 & 23.26 & 34.88 & 2.16 \\
\hline $\begin{array}{l}\text {...they do not affect agricultural } \\
\text { production very negatively in the region }\end{array}$ & 0.00 & 6.98 & 26.74 & 20.93 & 45.35 & 1.95 \\
\hline
\end{tabular}


The judgment to which the farmers highly agreed at a high rate $(56 \%)$ was that various diseases emerged in humans depending on the fuels used in thermal power plants. In actual fact, the concern of the farmers on this subject was not unreasonable. Because in previous studies conducted in Turkey, it was determined that $20 \%$ of the health problems that could be attributed to exposure to particulate matter were caused by the burning of the coal in the thermal power plants (Gacal, 2017). The presence of gases $\mathrm{SO} 2, \mathrm{CO}_{2}, \mathrm{NOx}$ in the waste gas that was released from coal thermal power plants may be taken in either by inhalation, directly or indirectly, through nutrients and water. It was stated that when people were exposed to an intense amount of these gases, the nervous system was affected, lung and respiratory problems were experienced, and cognitive development was affected negatively in children (Peden, 1997; Rusnak et al., 1997; Gacal, 2017). Secondly, the judgment to which the farmers highly agreed at a high rate $(53 \%)$ was that the reason that these power plants caused loss of fertility in the products that were grown in the regions where thermal power plants were located. This was followed by the judgment that these plants caused soil pollution, soil desertification and product quality disorders with a participation rate of $47.67 \%$. The farmers also approved "other" thermal power plant responses (average score: 1.95) that their thermal power plant would not have negative effects on agricultural production. In brief, the judgments of the farmers on the features of thermal power plants generally concentrated on damaging the soil, plants and human health. In many studies that were conducted on this subject support the judgments of farmers (Goncaoğlu et al., 2000; Aydemir, 2008; Karaca et al., 2007; Deniz, 2010; Kahraman, 2011; Özcan et al., 2014).

\section{Conclusion and recommendations}

It was shown in many previous studies that thermal power plants caused air pollution, water pollution and soil pollution and these impurities had negative effects on the living and agricultural products. Of course, the fuel used in thermal power plants was considered to be mostly coal, and the resulting damage caused by the gases that were produced in this process.

In the present study, how the thermal power plants were perceived by farmers was investigated with the sample case of the Suluova Region where the power plant was planned to be established. In the study, the majority of the farmers stated that it was important to establish thermal power plants to meet the energy needs of the country; however, the place of the establishment for these thermal power plants must be selected better. On the other hand, the farmers were also very concerned about the negative impacts of the thermal power plants on human health, agricultural lands and products, the vegetation cover, and all other living things. For this reason, the farmers who participated in the study wanted to stop the establishment of the thermal power plant in question. As a matter of fact, following the questionnaire stage of our study, the EIA process of the thermal power plant, which was planned to be established in the region by Gürmin Enerji Madencilik Sanayi ve Tic. Inc., was terminated with the justification that there were several shortcomings. Although it changes every year, the share of the thermal power plants in electricity production of Turkey is about $70 \%$. It seems that the dominance of the thermal power plants in producing electricity with domestic sources will continue for a long time in Turkey which is dependent to external sources in terms of energy raw material. In this sense, the benefits of the thermal power plants must also be brought to the forefront. Especially the benefits like using domestic coal, the fact that 
coal may be transported to all areas for installation, the resulting steam and water allowing low-cost electricity production may be considered. In this sense, increasing the efficiency of the existing thermal power plants, minimizing the damage that is given to the environment, providing maximum occupational health and work safety, prioritizing the use of domestic coal and biomass instead of the imported ones, and ensuring the establishment of thermal power plants with environmentally-friendly technologies are important.

\section{REFERENCES}

[1] Adriano, D. C., Page, A. L., Elseewi, A. A., Chang, A. C., Straugham, I. (1980): Utilization and disposal of fly ash and other coal residues in terrestrial ecosystems. A review. - Journal of Environment Quality 9: 333-444.

[2] Aydemir, G. (2008): The determination of the effects of Afşin-Elbistan Power Plant emissions on regional soils. - Master Thesis, Ankara University.

[3] Baba, A., Kaya, A., Birsoy, Y. K. (2003): The effect of Yatağan Thermal Power Plant (Muğla Turkey) on the quality of surface and ground waters. - Water, Air, and Soil Pollution 149: 93-111.

[4] Bunzl, K., Rosner, G., Schmindt, W. (1983): Distribution of lead, cobalt and nickel in the soil around a coal fired power plant. - Z. Pflanenernaehr. Bodenk 146: 705-713.

[5] Deniz, M. (2010): Effect of thermal power plant pollution on mineral nutrition and antioxidative defence mechanism on eucalyptus and Morus species. - PhD thesis, Çukurova University Graduate School of Naturel and Applied Sciences, Adana.

[6] Gacal, F. (2017): The effects of coal power plants on human health, health and environment association (HEAL). - http://www.komuruzer.com/(2017):08/komurlutermik-santrallerin-insan.html.

[7] Goncaloğlu, B. İ., Ertürk, F., Ekdal, A. (2000): Comparison of thermal power plants and nuclear power plants in terms of environmental impact assessment. - Ecology Environmental Journal 9(34): 9-14.

[8] Kahraman, Y. (2011): Possibility of using Afsın-Elbistan Coal Power Plant Ashes in Agriculture. - Kahramanmaras Sutcu Imam University Institute for Graduate Studies in Science and Technology Department of Soil Science and Plant Nutrition, Kahramanmaraş.

[9] Karaca, A. (1997): Effects of Afsin-Elbistan Thermal Power Plant emissions on physical, chemical and biological properties of environmental soils. - Ph. D. Thesis, Ankara University Institute of Science and Technology, Ankara.

[10] Karaca, A., Türkmen, C., Arcak, S., Haktanır, K., Topçuoğlu, B., Yıldız, H. (2005): The determination of the effect of Cayirhan coal-fired power plant emission on heavy metals and sulphur contents of regional soils. - Ankara University Journal of Environmental Sciences 1(1): 17-25.

[11] Karaca, A., Turgay, O. C., Karaca, S., Sağlam, M., Türkmen, F., Deviren, S., Türkmen, N. (2007): Effects of Seyitömer Thermal Power Plant Emissions on Environmental Soils. - Unpublished Project, Ankara University.

[12] Mejsrik, V., Suacha, J. (1988): Concentration of Co, Cr, Cd, Ni and Zn in crop plants cultivated in the vicinity of coal fired power plant. - The Science of the Total Environment 72: 57-67.

[13] Ministry of Energy and Natural Resources (2018): World and Turkey's Energy and Natural Resources View. http://www.enerji.gov.tr/File/?path=ROOT\%2f1\%2fDocuments\%2fEnerji\%20ve\%20Tab ii\%20Kaynaklar\%20G\%c3\%b6r\%c3\%bcn\%c3\%bcm\%c3\%bc\%2fSayi_15.pdf enerji.gov.tr. 
[14] MMO (Chamber of Mechanical Engineers) (2017): Thermal power plants in Turkey, 2017. - https://www.mmo.org.tr/kitaplar/turkiyede-termik-santraller-(2017):oda-raporu.

[15] Onacak, T. (1999): Environmental impacts of coal thermal power plants fed and solid waste combustion resulting in Turkey. - Ph. D. Thesis, Hacettepe University Institute of Science, Ankara.

[16] Özcan, İ., Bahadıroğlu, C., Bozdoğan, H. (2014): A research on the causes drying of seedlings planted in the areas of Afşin-Elbistan Thermal Power Plant environmental excavation casting standing. - Nevsehir Journal of Science and Technology 3(1) 8-16.

[17] Pacyna, J. M. (1987): Atmospheric Emissions of As, Cd, Pd, and $\mathrm{Hg}$ from High Temperature Processes in Power Generation and Industry. - In: Hutchinson, T. C., Meema, K. M. (eds.) Lead, Mercury, Cadmium and Arsenic in the Environment. John Wiley \& Sons Ltd, Chichester, UK.

[18] Peden, D. B. (1997): Mechanisms of pollution-induced airway disease: in vivo studies. Allergy 38: 37-44.

[19] Rusznak, C., Bayram, H., Devalia, J. L., Davies, R. J. (1997): Impact of the environment on allergic lung diseases. - Clin Exp Allergy 27: 26-35. 